\title{
SINERGITAS PERPUSTAKAAN DALAM MEMBANGUN KOMUNIKASI ILMIAH (SCHOLARLY COMMUNICATION) PADA ERA DIGITAL
}

\author{
Hartono \\ Kepala Bidang Layanan Jasa Informasi dan Kerjasama Perpustakaan \\ UPT Perpustakaan Bung Karno Blitar \\ kartonohary@yahoo.co.id
}

Kemajuan IImu Pengetahuan dan Teknologi (IPTEK) antara lain ditandai membanjimya informasi (information exsplotions). Adanya berbagai invasi dalam abad modern ini telah membawa kemajuan berbagai praktek penelitian dari berbagai disiplin ilmu. Itu semua muncul karena adanya kegiatan komunikasi ilmiah. Proses komunikasi ilmiah merupakan proses penyampaian pesan antara komunikan dan komunikator pada tataran tradisi akademik ilmiah yang melibatkan berbagai komponen mulai dari pencipta informasi (ilmuwan, pengarang, inventor) kepada pengguna informasi. Komunikasi ilmiah juga melibatkan berbagai komponen pendukung semacam penerbit, penjual, agen dan took buku, organisasi, perpustakaan, pusat dokumentasi, dan dukungan teknologi informasi. Mengkaji tugas pokok dan fungsi (tupoksi) Perpustakaan Proklamator Bung Karno, bahwa perpustakaan sebagai lembaga/institusi yang bertugas dalam menghimpun, mengelola, mengembangkan, melestarikan, mendayagunakan, dan melayankan koleksi perpustakaan Bung Karno. Dalam upaya membangun akses informasi, koleksi perpustakaan Bung Karno terdiri dari berbagai media textual maupun digital. Kemudian ditinjau penyebaran koleksi Bung Karno tersebar di seluruh Indonesia dan berbagai negera didunia. Dalam upaya mengembangkan komunikasi ilmiah yang lebih maksimal maka Perpustakaan Proklamator Bung Karno membangun sinergitas dan penguatan peran sebagai berikut: Pertama, perpustakaan Bung Karno perlu membangun sinergi infrastruktur komunikasi ilmiah yang melibatkan berbagai komponen pendukung semacam penerbit, penjual, agen dan toko buku, organisasi, perpustakaan, dan pusat dokumentasi. Kedua, perpustakaan perlu penyediakan infrastruktur untuk publikasi dengan akses terbuka (open access), koleksi e-resources pada akses ke jurnal ilmiah khususnya subjek Bung Karno. Ketiga, perpustakaan perlu membangun tempat penyimpanan (repositories) yang menyediakan akses pada arsip data serta dokumen digital yang dihasilkan dari karya-karya penelitian untuk kepentingan penelitian tentang Sukarnologi. Keempat, perpustakaan perlu mengoptimalkan peran dan fungsi perpustakaan untuk mendukung kegiatan riset tentang Sukarno.

Kata Kunci : perpustakaan, komunikasi ilmiah dan Era Informasi

\section{Pendahuluan}

Kemajuan teknologi informasi dan komunikasi seiring yang semakin pesat ditandai dengan perubahan berbagai aspek kehidupan masyarakat yang berimbas pada perilaku orang dalam mencari informasi juga pengembangan pada diseminasi informasi. Kondisi ini berdampak terhadap lembaga bidang informasi publik termasuk perpustakaandalammelakukantransformasi pengetahuan dan upaya membangun siklus pengembangan komunikasi ilmiah (scholarly communication).

Perlu diketahui bahwa dalam era informasi ditandai dengan adanya trend kemajuan teknologi informasi dan 
komunikasi serta modernitas segala aspek kehidupan bangsa, yang mengakibatkan terjadinya perubahan yang sangat signifikan khususnya dalam bidang perpustakaan. Kecenderungan memproduksipengetahuan dari segala subjek bidang informasi termasuk perpustakaan dituntut untuk membangun komunikasi ilmiah dengan membangun sinergitan berbagai lintas sektoral seperti penerbit, toko buku, pusatpusat informasi bahkan pusat-pusat koleksi memorabilia Bung Karno ke seluruh dunia.

Dengan mengkaji tugas pokok dan fungsi (tupoksi) perpustakaan, Perpustakaan Proklamator Bung Karno, sebagai lembaga/institusi yang bertugas menghimpun, mengelola, mengembangkan, melestarikan dan mendayagunakan serta melayankan koleksi perpustakaan, dalam upaya mengembangkan kualitas layanan perpustakaan terhadap koleksikoleksi perpustakaan Bung Karno. Salah satu upaya dalam mengadopsi kemajuan teknologi informasi dan komunikasi serta tuntutan jaman kegiatan yang dilakukan oleh perpustakaan adalah membangun portal database untuk mengembangkan layanan perpustakaan digital. Sekaligus mengimplementasikan otomasi terintegrasi, membangun kerjasama digital resource sharring, melanggan databases elektronik baik melakukan pembelian maupun alih media serta akses lingk eksternal dalam memenuhi kebutuhan informasi.

\section{Berdasarkan}

database,

Perpustakaan Proklamator Bung Karno memiliki koleksi perpustakaan sebanyak 72.158 judul dan 159.594 eksemplar. Sebagian koleksi tersebut memiliki koleksikoleksi digital yang cukup besar jumlahnya meliputi koleksi digital teks, film, video, audio yang bisa dapat diakses secara offline maupun online melalui website. Disisi lain juga membangun sistem otomasi secara terintegrasi, mengembangkan alih media koleksi Bung Karno, layanan internet, layanan wifi/hotspot dalam gazebo dan layanan e-resources dengan link Perpustakaan Nasional RI. Potensi sumberdaya koleksi digital yang sangat besar perlu didukung kebijakan organisasi dan manajemen, teknologi, dan kebijakan akses dengan regulasi pada perpustakaan digital, yang memadai yang berdampak sangat besar pada aksesibilitas informasi dan kualitas layanan perpustakaan.

Kemajuan ilmu pengetahuan dan teknologi informasi ini ditandai adanya perubahan segala aspek kehidupan bangsa, yang membawa pengaruh terhadap perubahan-perubahan yang dahsyat, yang tidak dapat diperkirakan sebelumnya terkecuali pada pandangan futuristik (Sulistyo-Basuki, 2014). Dalam era informasi yang ditandai dengan kemajuan ilmu pengetahuan, teknologi komputer dan internet menjadikan dunia terasa datar "flat" kemudin dalam -bidang informasi terasa bahwa berbagai kemajuan dan modernitas berdampak pada segala aspek prilaku pencarian informasi. Kondisi ini sebenarnya memiliki arti penting bagi lembaga yang bergerak dibidang informasi termasuk perpustakaan. Aksesibilitas informasi dan desiminasi informasi sebagai upaya memproduksi pengetahuan semakin berkembang. Konsep modernitas dan kemajuan teknologi informasi ini akan membawa proses lebih cepat dalam mengembangkan komunikasi ilmiah yang dirasa mampu mendesiminasi serta memproduksi pengetahuan dengan seoptimal mungkin.

Kemudian dalam konteks komunikasi ilmiah banyak pihak yang berperan sebagai aktor dalam proses produksi sebuah karya ilmiah yang akhirnya menghasilkan sebuah pengetahuan. Aktor yang paling berperan dalam proses komunikasi ilmiah ini antara lain adalah pengarang (author), penerbit, editor, distributor, pengguna/masyarakat dan perpustakaan. Dinamika peran dalam mendesiminasii sebuah karya ternyata perlu proses yang panjang tidak saja pengarang namun perpustakaan sebagai 
lembaga informasi memiliki potensi besar berkontribusi dalam komunikasi ilmiah.

Dalam konteks aksesibilitas informasi, fungsi :perpustakan dikatakan sebagai elemen krusial dalam proses komunikasi informasi. (Yusuf, 2009) menyebutkan organisasi informasi dan pengolahan sumber-sumber informasi tidak lain tujuannya adalah untuk kemudahan pemanfaatannya oleh masyarakat. Tidak ada aspek kegiatan dan proses kerja di perpustakaan dan pusat-pusat informasi yang tidak melibatkan proses komunikasi. Proses komunikasi ilmiah pada dasarnya adalah proses penyampaian pesan antara komunikan dan komunikator pada tataran tradisi akademik ilmiah yang melibatkan berbagai sub komponen mulai dari pencipta informasi (ilmuwan, pengarang, inventor) kepada pengguna informasi. Komunikasi ilmiah juga melibatkan berbagai komponen pendukung semacam penerbit, penjual, agen dan toko buku, organisasi, perpustakaan, pusat dokumentasi, dan dukungan teknologi informasi. Dengan demikian, infrastruktur informasi berupa koleksi digital perpustakaan menjadi hal yang tidak bisa diabaikan.

Tulisan ini lebih fokus merupakan kajian teoritis kepustakawanan yang dihubungkan dengan strategi penguatan peran Perpustakaan Proklamator Bung Karno dalam mengembangkan komunikasi ilmiah. Dalam tulisan ini bertujuan memperluas wacana pembaca mengenai sifat multidisipliner dan interdisipliner dari bidang ilmu perpustakaan dan informasi terkait pengembangan komunikasi ilmiah khususnya subjek-subjek Bung Karno.

\section{Konsep Komunikasi IImiah (Scholarly Communication)}

Kemajuan ilmu pengetahuan dan teknologi (Iptek) antara lain ditandai adanya ledakan informasi (information exsplotions). Kondisi ini memiliki arti penting bagi lembaga yang bergerak dalam bidang informasi termasuk perpustakaan. Perkembangan iptek :merupakan inovasi dalam berbagai subjek tersebut merupakan akumulasi pengetahuan yang dihasilkan melalui kegiatan komunikasi ilmiah. Komunikasi ilmiah (scholarlycommunication)merupakan bagian integral dalam pengembangan ilmu pengetahuan. Perpustakaan sebagai pusat informasi sekaligus sebagai elemen krusial dalam proses komunikasi informasi ilmiah belum dikembangkan secara proporsional oleh lembaga informasi khususnya perpustakaan di indonesia. Perpustakaan hanya disibukan dalam kegiatan rutinitas kegiatan baca tulis yang belum bergerak dalam komunikasi ilmiah sebagaimana dikembangkan berbagai negara maju.

Ranah perpustakaan dan dokumentasi pada dasarnya membutuhkan sebuah perluasan konteks keilmuan yang tidak saja sebatas pada konsep perpustakaan konvensional. Salah satu implikasi praktis atas kebutuhan perluasan multidisipliner keilmuan muncul dalam konsep komunikasi ilmiah (scholarly communication) (Siswadi, 2009). Berdasarkan pengalamannya sebagai pustakawan di Universitas Indonesia (UI) ketika didatangi seorang kandidat doktor pengguna perpustakaan yang mencari artikel jurnal dengan judul dan deskripsi bibliografis yang spesifik digunakan sebagai penguat asumsi sebuah teori yang akan dituliskan dalam disertasinya. Berbagai literatur jurnal ilmiah baik yang tekstual (printed) maupun digital (e-journal) sudah ditelusur dan hasilnya nihil. Sebagian besar e-journal yang ditelusur ternyata hanya berisi abstrak yang dirasa kurang komprehensif bagi sang kandidat doktor. Sampai akhirnya diperoleh solusi terakhir yaitu menghubungi langsung penulis artikel lewat e-mail via perpustakaan (Siswadi, 2009).

Prosedur yang tidak pernah terpikirkan oleh pemustaka untuk menghubungi langsung sang produsen informasi berdasarkan deskripsi bibliografis yang ada dalam abstrak literatur yang 
dibutuhkan. Melalui perkembangan teknologi informasi dan komunikasi telah mempermudah pengguna (konsumen) informasi untuk berhubungan langsung dengan para ilmuwan, peneliti, inventor, penulis karena di jaringan internet banyak sekali direktori on-line yang menyediakan informasi mengenai kontak berbagai produsen informasi. Langkah yang diambil adalah menelusur kembali informasi artikel jurnal menggunakan mesin pencari (search engine).

Siswadi (2009) mengemukakan "pada umumnya hasil penelusuran dalam bentuk abstrak bukan full-text artikel. Untuk mendapatkan secara full-text biasanya si penelusur perlu membeli". Umumnya abstrak memberikan informasi singkat berkaitan dengan artikel tersebut, seperti judul artikel; sumber jurnal; nama pengarang ditambah dengan e-mail serta ringkasan artikel. Menurut Prahastuti dalam (Siswadi, 2009) komunikasi untuk informasi penelitian akan lebih efisien jika sumber formal (cetak) dilengkapi dengan sumber informal atau percakapan. Tetapi, permasalahnya alamat e-mail pengarang sebagai sumber informal tidak selalu muncul.

Proses komunikasi ilmiah juga tidak selalu terkait dengan perpustakaan. Ilustrasi di perpustakaan UI tersebut mungkin hanya sebagian kecil dari siklus informasi ilmiah. Penggunaan informasi baik level mikro dan makro menungkinkan proses komunikasi ilmiah berlangsung di level individu. Modelmodel pencarian informasi (information search, information seeking) dari Ellis, Kuhltau (Pendit, 2002) dapat diasumsikan sebagai embrio proses komunikasi ilmiah pada level individu (individual level). Pemustaka (user) maupun pustakawan terhubung dalam sebuah intermediary process, yang dalam siklus informasi peran antara ilmuwan, peneliti, dan author sebagai komunikator untuk berhubungan langsung dengan pembaca (komunikan) menjadi sangat signifikan.
Manfaat yang dapat diperoleh adalah memberikan alternative solusi pemahaman bahwa berbagai stakeholder dalam ilmu perpustakaan dan informasi baik pustakawan, kolega dosen, mahasiswa ilmu perpustakaan, mahasiswa ilmu komunikasi, pemustaka, dan praktisi penerbitan terkait sebuah sistem komunikasi ilmiah yang cenderung, berdasarkan pemahaman penulis, dilihat secara parsial.

\section{Proses Komunikasi dalam Komunikasi IImiah}

Komunikasi atau communication berasal dari kata latin communis yang berarti "sama", communico, communication, atau communicare yang berarti "membuat sama" (to make common). Komunikasi menyarankan bahwa suatu pikiran, suatu makna, atau suatu pesan dianut secara sama (Mulyana, 2009). Menurut Shannon dan Weaver (Sulistyo-Basuki, 1996: 18) komponen komunikasi terdiri atas sumber (source), pemancar (transmitter), saluran (channel), penerima (receiver) dan tujuan (destination). Model komunikasi tersebut dikenal sebagai model transmisi yang banyak diadopsi dalam bidang bidang telekomunikasi.

Namun demikian (Littejohn, 2002) melihat proses komunikasi berdasarkan perspektif yang non transmisi. Littejohn menyebut : "communication involves understanding how people behave in creating, exchanging, and interpretating message. consequently, communication inquiry combines both scientific and humanistic methods". Konsep pendekatan scientific scholarship dalam komunikasi menurut Littlejohn selalu diasosiasikan dengan objektifitas. Proses komunikasi terjadi antara sesama manusia melalui berbagai media seperti suara, sinyal, surat, telepon, televisi, buku, media cetak. Kemudian Motley dalam (Littlejohn, 2002) berpendapat bahwa komunikasi adalah transmisi informasi, baik bersifat verbal maupun non verbal. Berbagai perspektif 
definisi proses komunikasi inilah yang akan mengantarkan pada pendekatan komunikasi ilmiah yang 'lebih banyak terjadi dalam dimensi riset, inquiry, dan invensi dari para ilmuwan (researcher).

Sebuah sistem komunikasi ilmiah, konsep pengguna informasi merupakan bagian yang tidak terpisahkan, dan menjadi sentral dari keseluruhan proses baik dalam taraf afektif, kognitif, dan tingkah laku. Pengguna informasi merupakan pihak pengambil keputusan yang menentukan proses mulai dari munculnya kebutuhan, proses penilaian, pencarian, sampai taraf pemanfaatan informasi serta proses komunikasi ilmiah. Menurut SulistyoBasuki, disebutkan bahwa kriteria pengguna informasi dapat dibedakan menjadi dua kriteria: (1) Kriteria Objektif, seperti kategori sosio-profesional, bidang spesialisasi, sifat kegiatan yang menyebabkan perlunya informasi dan alasan menggunakan sistem informasi. (2) Kriteria Sosial dan Psikologi, sepertisikap dan nilaipenggunamenyangkut informasi pada umumnya, dan hubungan dengan unit informasi pada khususnya, sebab dan alasan yang berkaitan dengan perilaku mencari informasi dan komunikasi, perilaku sosial, serta profesional pengguna.

Dua kriteria di atas belum memberikan gambaran jelas tentang pengguna informasi, maka masih menurut Sulistyo-Basuki, pengguna informasi dibedakan jenisnya: (1) Pengguna yang belum terlibat dalam kehidupan aktif, seperti mahasiswa dan pelajar. (2) Pengguna yang. mempunyai pekerjaan, informasi yang diinginkan berupa informasi yang berkaitan dengan pekerjaan mereka. Jenis pengguna dibedakan atas: (a) Berdasarkan aktifitas utama, misalnya manajemen, riset, serta pengembangan produksi, (b) Berdasarkan cabang aktifitas/bidang spesialisasi, misalnya pegawai negeri, perindustrian. Dan (c) Berdasarkan tingkat pendidikan dan tanggung jawab, misalnya profesional, teknisi, asisten, administrasi. (3) Pemakai umum yang memerlukan informasi umum untuk kepentingan khusus, misalnya masyarakat yang ingin mengetahui informasi tentang olahraga untuk mengikuti kuis (Andriani, 1998).

Sementara itu (Atherton, 1986) membagi jenis pemakai informasi menjadi tiga kelompok penting khususnya di bidang penelitian ilmu pengetahuan dan teknologi sesuai dengan jenis kegiatan dimana mereka terlibat, yaitu: (1) Para peneliti ilmu-ilmu dasar dan terapan; (2) Para praktisi dan teknisi yang terlibat dalam pengembangan kegiatan teknologi dan pelaksanaan kegiatan industri; (4) Para manajer, perencana, dan pengambil keputusan lainnya yang terlibat dalam mengkoordinasikan kegiatan dibidang ilmu pengetahuan dan teknologi baik sektor swasta maupun pemerintah. Tiga kelompok yang diidentifikasikan di atas didefinisikan secara sangat umum (luas) dengan demikian tidakbersifatlengkap. Mereka tidak mencakup misalnya kelompok-kelompok besar seperti guru-guru dan siswa. Atherton juga berpendapat, 'pengguna informasi dapat dikenali ciri-cirinya. Hal tersebut mencakup tipologinya, ketergantungannya akan kebutuhan informasi dalam pekerjaan mereka, tujuan dan penggunaan informasi yang dilakukannya, umurnya, kualifikasi, jabatan/kedudukan profesionalnya, dan sejumlah ciri-ciri lain (Atherton, 1986).

Fjallbrant mengidentifikasi secara lebih rinci tentang beberapa komponen yang berhubungan dan memiliki kaitan erat dalam pengguna informasi dalam sistem komunikasi ilmiah: (1) Para ilmuwan yang memiliki keinginan untuk menerbitkan karya-karyanya, masuk dalam kelompok penulis dan menjadi produser utama dari sebuah karya; (2) Para ilmuwan lainnya yang membaca karya berasal dari produser utama dan dikelompokkan sebagai kelompok pembaca, (3) Mahasiswa yang diposisikan sebagai pembaca. Kelompok pembaca lainnya yang tertarik pada karyakarya ilmiah dikelompokkan sebagai pembaca; (5) Para penerbit dikelompokkan 
sebagai produser kedua yang menerbitkan karya-karya dari masyarakat ilmiah (produser pertama); (6). Perpustakaan yang berperan dalam mengumpulkan dan menyebarluaskan jurnal dan buku-buku ilmiah kepada para pembaca dan berfungsi sebagai fasilitator bagi para pembacanya. (7) Penjual yang menjual buku dan jurnal ilmiah kepada para pembaca dan befungsi juga sebagai fasilitator; (8) Organisasi formal yang menangani pengakuan terhadap penemuan-penemuan penelitian dan penulis sebuah dokumen. Organisasi tersebut dikelompokkan sebagai konsumen, (9) Kelompok industri yang memanfaatkan hasil-hasil penelitian, dikelompokkan sebagaikonsumen, (10) Lembaga akademik yang melakukan evaluasi dan seleksi staf, dikelompokkan sebagai konsumen dan fasilitator produksi dan (11) Kelompok agama, yang mempengaruhi pelaksanaan dan pengambangan ilmu pengetahuan pada abad ke-17 dan 18.

\section{Komunikasi Ilmiah dan Trend Perpustakaan dalam Era Digital}

Era informasi, semua mengalami perubahan baik materi, kontiner, pengelola dan aksesibitas informasinya. $\mathrm{Hal}$ tersebut terjadi pergeseran antara konteks perpustakaan dan informasi. Menurut Harrod's Glossary of Library Terms menyatakan bahwa "Information scince as the study of information, its sources and development ussualy taken to refer to the role of scientific, industrial and specified libraries libraries and information units in the handling and dissemination of information". Secara lebih luas bahwa ilmu informasi merupakan bidang interdisipliner yang mempelajari ilmu perpustakaan dan ilmuilmu lainnya. Ilmu informasi mencakup cara bagaimana menginterpretasi, menganalisa, menyimpan dan mengambil kembali data dan informasi tersebut. IImu informasi merupakan dasar dari analisa komunikasi dan:basis data.
Dalam erà industri dan pertanian, bahwa indikator kekayaan seseorang adalah kepemilikan dan penguasaan tanah. Tetapi kemudian ketika era industri datang, yang dianggap kekayaan adalah penguasaan industri. Dengan datangya era informasi diyakini bahwa kekayaan yang sesungguhnya adalah modal intelektual dan kecerdasan (intelectual capital). Di Indonesia saat ini, terlihatbahwa era tersebut berlangsung secara serempak, namun sebagian besar penduduk Indonesia masih tergantung pada pertanian, sebagian lagi sudah masuk dan bergerak dalam bidang indutri informasi. Kekayaan alam Indonesia belum dapat menjamin kesejahteraan karena keterbatasan penguasaaan ilmu dan teknologi. Kecenderungan menuju. perpustakaan modern, maju, . elektronis merupakan ciri yang ditunjukan terhadap prilaku masyarakat dalam pengelolaan informasi.

Perubahan paradikma pustakawan yang menuntut perubahan dalam melayani pengguna. Pengguna perpustakaan harus dikenali dengan baik, perlakuan kepada mereka harus bervariasi. Pemustaka (users) adalah istilah umum yang digunakan, tetapi ada diantara mereka yang dikelompokkan sebagai anggota (members). Pembaca (readers), pemerhati (patrons), pelanggan (customers), ataupun sebagai klien (clients). Dengan demikian layanan kepada. masing-masing harus disesuaikan dengan kebutuhan dan kriterianya. Pustakawan harus proaktif memberikan jasanya, Pada hakikatnya perpustakaan adalah lembaga yang memberikan jasa. Oleh karena itu kepuasan pengguna harus menjadi target layanan.

Perubahan paradigma baru bagi pustakawan dimaknai bahwa yang semula perpustakaan sebagai gudang buku (book custodian) akan berevolusi menjadi perpustakaan modern multimedia yang dapat secara online, bahan pustaka semula berbasistextdanfisikkertas berubahmenjadi informasi yang dapat berupa informasi 
maupun elektonik digital. Kemudian peran pustakawan sebagai penjaga buku (book keeper) menjadi penyedia informasi (information provider). Untuk mendukung terciptanya layanan yang prima dan sesuai dengan tuntutan paradigm baru, maka penerapan, manajemen modern dalam pengelolaan perpustakaan menjadi suatu kebutuhan. Tantangan demi tantangan yang dihadapi semua profesi, termasuk profesi pustakawan harus diatasi melalui organisasi yang dikelola secara profesional.

Dalam kaitannya dengan kesiapan perpustakaan dalam mengembangkan komunikasi ilmiah sebagaimana peran perpustakaan dalam era informasi, ada perubahan yang signifikan. Menurut (Sulistyo-Basuki, 2014) menjelaskan bahwa peranan perpustakaan dimasa datang pada era informasi tetap sama yakni memiliki peranan dalam penyimpanan, pendidikan, informasi, pendidikan dan kultural. Lebih lanjut dijelaskan bahwa Pertama, peran penyimpanan, bahwa dalam era informasi digital peranan penyimpanan masih tetap dilakukan, karena banyaknya dokumen digital disamping dokumen cetak walaupun akan berubah menjadi perpustakaan digital. Kondisi tersebut juga akan timbul masalah hak cipta dokumen digital. Kedua, peran informasi bahwa perpustakaan akan mengarah informasi kualitatif dalam akses informasi internet dan sumber informasi digital. Ketiga, peran pendidikan bahwa perpustakaan akan menyediakan informasi dalam mendukung pendidikan sebagai upaya membangun kualitas pendidikan. Adanya internet mengurangi penan guru namun tidak menghilangkan pernan guru. Seiring dengan informasi kualitatif, perpustakaan tetap berfungsi pendidikan berupa penyediaan data dan informasi. Keempat peran penelitian, bahwa perpustakaan akan berperan dalam penyediaan koleksi - koleksi dalam format digital seperti dalam koleksi grey literature dalam mendukung penelitian. Kegiatan komunikasi ilmiah era informasi semakin lancer, dan akses yang luas terhadap tumbuhnya berbagai jurnal ilmiah. Peran perpustakaan semakin penting dalam menyediakan sumber informasi digital baik dalam bentuk tercetak, database $C D$ ROM maupun sumber informasi elektronik yang dapat diakses secara online melaui berbagai jaringan eksternal. Kelima, fungsi kultural bahwa peran perpustakaan tetap dipertahankan sebagai bagian kegiatan perpustakaan. Hasil kebudayaan akan tetap direkam, sebagian darinya akan disimpan di perpustakaan. Dengan kemudahan internet, perpustakaan dapat melaksanakan fungsi cultural lebih baik dari pada sekarang, berkat tersedianya teknologi informasi dan komunikasi (TIK) (Sulistyo-Basuki, 2014).

Demikian juga menurut menurut (Pendit, 2010) kaitannya kesiapan perpustakaan dalam mengembangkan komunikasi ilmiah sebagaimana peran perpustakaan dalam era informasi ada perubahan yang signifikan. Lebih lanjut dijelaskan bahwa perpustakaan tidak perlu mengubah fungsi utama yang kini dijalaninya, melainkan harus menyesuaikan dengan perkembangan jaman. Untuk itu perpustakaan harus bekerja keras meningkatkan efisiensi dalam menjalankan fungsi sebagai pengelola informasi. Perpustakaan dituntut untuk mengembangkan perpustakaan digital sebagai upaya mengatasi aksesibilitas informasi. Setiap perpustakaan memiliki tanggung jawab dengan tuntutan profesionalisme pengelolaan, guna menjawab perkembangan jaman dan merespon serta berusaha memenuhi kebutuhan pemakaiyang selaluberkembang (Sulistyo-Basuki, 2014).

Tersedianya berbagai sumber informasidan dengan kecanggihan teknologi informasi komunikasi memudahkan pengguna untuk dapat langsung mengakses informasi tanpa bantuan perpustakaan. Menurut Thomson dalam (Suwarno, .2016) peran perpustakaan dalam abad 21 adalah sebagai berikut : (a) Memberikan fasilitas akses terhadap elektronik bagi mereka yang 
tidak memilikiakses itu secarafisik, termasuk reproduksinya, (b) Membimbing pengguna mencari dan memiliki sumber informasi yang sesuai dengan kebutuhannya berdasarkan kemampuan profesionalisme yang dimiliki staf perpustakaan dan (c) Mengkoleksi, mengkatalog dan mengindeks bahan pustaka. Ketrampilan mengorganisasi informasi ini akan memberikan kemudahan untuk mengaksesnya baik untuk informasi dalam bentuk tercetak maupun versi elektronik.

Mencermati peran perpustakaan dalam abad 21 yang disebut-sebut era informasi sebagaimana dikemukakan Thomson tersebut bahwa perpustakaan perlu penguatan peran dan kontribusi dalam berbagai hal antara lain: pertama dalam aspek manajemen perpustakaan, bahwa manajemen perpustakaan diarahkan pada manajemen informasi perpustakaan, kedua dalam aspek kebijakan bahwa perpustakaan memiliki komitmen dalam penetapan perencanaan dan pengembangan perpustakaan berbasis teknologi informasi, ketiga dalam aspek sistem informasi perpustakaan mampu secara teknis mengimplementasikan sistem automasi perpustakaan secara terintegrasi, pengembangan perpustakaan digital melalui pengembangan koleksi sumberdaya digital, menyediakan koleksi sumber informasi digital baik melalui melanggan, alih media produksi sendiri dan link akses internal dan membangun kerjasama dan jaringan informasi digital.

Thomson (1982) dalam bukunya berjudul "The End of Libraries" bahwa perpustakaan dalam era informasi akan mengalami perubahan baik isi (content) maupun bentuk luarnya (kontainernya) lebih lanjut bahwa :

"the role of library in a paperless society as (a) libraries will be needed to provide online access to resources for individuals who, for one reasosn or another, do not have their own terminal. (b) libraries will be centres in which trained personal will be available ta assist to user to exploit the resources offered by database and databanks and (c) libraries my serve as "printout centres" since high-speed printers maynot be available to all user of terminals (Thomson, 1982).

Kemajuan teknologi informasi dan komunikasi memungkinkan peran perpustakaan untuk mengembangkan ide sebagaimana dikutip dalam Suwarno (2016) bahwa ada beberapa ide perkembangan perpustakaan dengan memanfaatkan teknologi informasi antara lain (a) mengimplementasikan SMS gateway, (b) menerapkan interactive learning ynag interaktif sebagai media pembelajaran masyarakat secara online, (c) mengembangkan dan mengimplementasikan independent learning melalui teknologi Iphad, tablet, blackberry Android dan sejenisnya, (d) Melakukan online reservation dalam menunjang kualitas layanan perpustakaan. dan (e) mengimplentasikan online library information retrieval atau online public access catalog (OPAC) untuk mendukung sistem temu balik informasi.

Dalam upaya mengembangkan komunikasi ilmiah dalam era informasi secara lebih eksplisit disampaikan menurut Hurd, Julie, M (2004) dijelaskan :

"Communicatuion in science has envolved from process dependent in print-on-paper to increasingly reliant on electronic media as database have repleaced indexes and journals have shifted to electronic formats. This migration from print to electronic has transformed the roles of virtually all participants in the sytem of scientific communication"

Dalam pemikiran tersebut dijelaskan bahwa komunikasi ilmiah akan terjadi transformasi dan migrasi media yang termanfaatkan dari basis kertas dan tercetak menuju digitalisasi atau elektronik. Hal serupa juga disampaikan Rowland, Ian and David Nicholas (2005) judul artikelnya scholarly communication in the digital dijelaskan bahhwa : 
"this paper aims to make a substantial contribution to on going debate about the potential of open access publishing and intituational repositories to reform to scholarly communication symitem. It present the views of senior authors on these issues and contextualities them within the brader frame work of their jounal publishing behavior and.preferens"

Dalam paparan diatas menunjukan bahwa akan terjadi proses transformasi dalam pengembangan komunikasi ilmiah dalam era informasi yang sangat luar biasa pada kegiatan komunikasi ilmiah dengan hadirnya media elektronik dan digital.

\section{Sinergitas dan Penguatan Peran Perpustakaan Bung Karno}

Upaya mengembangkan komunikasi ilmiah yang lebih - maksimal terhadap perpustakaan khususnya Perpustakaan Proklamator Bung Karno mengambil langkah-langkah strategis sebagai berikut: Pertama, perpustakaan Bung Karno perlu membangun sinergi infrastruktur komunikasi ilmiah yang melibatkan berbagai komponen pendukungsemacampenerbit, penjual, agen dan toko buku, organisasi, perpustakaan, pusat dokumentasi. Perpustakaan sebagai mata rantai dalam kegiatan komunikasi ilmiah baik dengan pengarang, penerbit, toko buku dan pembaca secara bersama sama memiliki peran strategis dalam mengembangkan komunikasi ilmiah. Lembaga perpustakaan dan pusat dokumentasi mutlak menjadi katalisator dalam proses komunikasi ilmiah khususnya subjek Bung Karno. Kedua, perpustakaan perlu menyediakan infrastruktur untuk publikasi dengan akses terbuka (open access), khususnya koleksi e-resources khususnya akses ke jurnal ilmiah khususnya subjek Bung Karno. Ketiga, perpustakaan perlu membangun tempat penyimpanan (repositories) yang menyediakan akses dan mengarsip data serta dokumen digital yang dihasilkan dari karya-karya hasil penelitian dan untuk kepentingan penelitian tentang Sukarnologi. Keempat, perpustakaan perlu mengoptimalkan peran dan fungsi perpustakaan untuk mendukung kegiatan riset tentang Sukarno. Kelima, Perpustakaan Bung Karno harus mampu menjadi garda terdepan dalam diseminasi berbagai media komunikasi ilmiah subjek Bung Karno baik tekstual dan elektronik agar optimal dimanfaatkan para peneliti. Perpustakaan akan menjadi bagian yang tidak terpisahkan dalam komunikasi ilmiah. Keenam, perpustakaan Bung Karno perlu melakukan digitalisasi koleksi khusus Bung Karno. Saat ini beberapa perpustakaan sudah melakukan digitalisasi koleksinya dan hasilnya dapat diakses dengan mudah;

\section{Penutup}

Proses komunikasi ilmiah pada dasarnya adalah proses penyampaian pesan antára komunikan dan komunikator pada tataran tradisi akademik. ilmiah yang melibatkan berbagai sub komponen mulai dari pencipta informasi (ilmuwan, pengarang, inventor) kepada pengguna informasi. Komunikasi ilmiah juga melibatkan berbagai komponen pendukung semacam penerbit, penjual, agen dan toko buku, organisasi, perpustakaan, pusat dokumentasi, dan dukungan teknologi informasi. Dengan demikian, infrastruktur informasi berupa koleksi digital perpustakaan menjadi hal yang tidak bisa diabaikan.

Lembaga perpustakaan, informasi dan pusat dokumentasi juga Perpustakaan Bung Karno mutlak menjadi katalis dalam proses komunikasi ilmiah. Perpustakaan sebagai lembaga yang menjadi penyedia sumber informasi ilmiah, harus mampu mengoptimalkan fungsinya untuk mendukung kegiatan riset. Tidak berfungsinya perpustakaan dalam memaksimalkan fungsi riset akan menyebabkan proses komunikasi ilmiah menjadi tidak efektif. Perpustakaan dan pusat dokumentasi harus mampu menjadi garda terdepan dalam diseminasi berbagai 
media komunikasi ilmiah baik tekstual dan elektronik agar optimal dimanfaatkan para peneliti. Perpustakaan akan menjadi bagian yang tidak terpisahkan dalam komunikasi ilmiah.

Kontribusi Perpustakaan Bung Karno dalam Komunikasi Ilmiah bahwa perpustakaan sebagai lembaga yang menjadi penyedia informasi ilmiah, harus mampu mengoptimalkan fungsinya untuk mendukung pengembangan koleksi Bung Karno dalam kegiatan riset khususnya tentang Bung Karno. Tidak berfungsinya perpustakaan dalam memaksimalkan fungsi riset akan menyebabkan proses komunikasi ilmiah menjadi tidak efektif. Perpustakaan dan pusat dokumentasi harus mampu menjadi garda terdepan dalam diseminasi berbagai media komunikasi ilmiah baik tekstual dan elektronik agar optimal dimanfaatkan para peneliti.

\section{Penguatan peran perpustakaan} Bung Karno dalam mengembangkan komunikasi ilmiah menjadi sangat strategis khususnya terkait produksi pengetauan subjek Bung Karno. Penguatan peran tersebut yang perlu dilakukan adalah membangun akses terbuka (open access), adalah membangun tempat penyimpanan (repositories) yang menyediakan akses dan mengarsip data serta dokumen digital yang dihasilkan dari karya-karya hasil penelitian dan untuk kepentingan perpustakaan Bung Karno dan membangun sinergi komponen komunikasi ilmiah antar perpustakaan, penerbut, pengarang dan membangun kerjasama dalam maupun luar negeri terkait pengembangan akses sumber informasi sukarno dari berbagai media.

\section{Daftar Pustaka}

Amin $T$, Kurniawan. Konsep Komunikasi Ilmiah dalam Pemanfaatan Informasi di Perpustakaan dan Informasi di Perpustakaan dan Dokumentasi. Jumal Komunikasi Masa Vol 4 No. 1 Januari.2011.
Atherton, Pauline. (1986). Sistem Dan Pelayanan Informasi. Terj. Bambang Hayanto. Jakarta: Arga Kencana Abadi.

Bjork, Bo-Christer. (2007). "A Model of Scientific Communication as A Global Distributed Information Systems" in Information Research. Vol 13 No. 4. Paper 372 http:// informationR/ir/13-4/paper372. htm [diakses 19 November 2010]

Buck, Anne M., Richard C. Flagan., Besty Coles. (1999). "Scholar's Forum: A New Model For Scholarly Communication" in Paper California Institue of Technology, Pasadena, CA. March 1999: 23 - 39 http:// library.caltech.edu/publication/ ScholarsForum [diakses 16 November2010]

Crawford, Susan Y. Hurd, Yulie M. and Weller, Ann C. 1996. From print to electronic. The Transpormation of scientific communication. ASIS Monograph Series Medford. NJ : Information To Day

Fjallbrant, Nancy. (1997). "Scholarly Communication: Historical Development and New Possibilities" in Paper IATUL Conference Troindheim 1997: 20 - 52 http:// www.iatul.org/doclibrary/public/ Conf_Proceedings/1997/Fjallbrant. doc [diakses 16 November 2010]

Gimenez - Toledo, Elea. 2013. Black holes of Communication Scientific Communication and Meta Research. Communicar 41. XXI. 2013.

Hartono. 2016. Manajemen Perpustakaan Sekolah : Menuju Perpustakaan Modern dan Profesional. Yogyakarta AR-Ruzz Media.

Houghton, John W., Colin Steele, Peter Sheehan. (2008). "Scholarly Communication Costs in Australian 
Higher Education" dalam Higher Education Management and Policy Vol. 20. No. 3 2008: 27 - 44 http:// www.cfses.com/documents/ wp24. pdf [diakses 16 november 2010]

Hurd, Julie. M. 2004. Scientific Communication : New Roles and New Player. Science \& Technology Libraries 25 (1-2) (2004) : 5 - 22

Laksmi, Tamara Adriani Sosetyo-Salim dan Ari Imansyah. Manajemen Informasi : Teori dan Praktek. Jakarta : Penaku

Laksmi.2006. Tinjauan Kultural terhadap Kepustakawanan : Inspirasi dari Sebuah Karya Umberto Eco. Depok: Fakultas IImu Pengetahuan Budaya.

Lewis, David W. (2007). "Library Budgets, Open Access and The Future of Scholarly Communication". Paper in IUPUI University Library Indiana University-Purdue University Indianapolis. November 2007: 1 - 4 http:// sn.pronetos. com/documents/0000/0046/ DLewis_Open_Access_Scholarly Communication.pdf [diakses 17 November 2010]

Littlejohn, Stephen W. (2002). Theories of Human Communication. Seventh Edition.

Belmont CA.: Wadsworth Thomson Learning.

Mulyana, Deddy. (2009). Ilmu Komunikasi: Suatu Pengantar. Cetakan Ketiga Belas.Bandung: Remaja Rosdakarya.

Nicholas D. Huntington, P. and Rowland I (2005a). Open acces journal publishing : the views of some of the worlds senior authors. Jornal of Documentation Vol. 61 No. 4 page. $497-519$

Olander, B. (2008). "Scholarly Communication in Transition:
Computer Scientist Information Behavior Over Twenty Years" in Information Research Vol 13 No. 4 paper $376 \mathrm{http}: / /$ informationR/ ir/13-4/paper376:htm [diakses 19 November 2010]

Oldlyzko, Andrew. (2002). "The Rapid Evolution of Scholarly Communication" in Learned Publishing Vol. 15 No 1. January 2002: 7 - 16 Error! Hyperlink reference not valid. [diakses 16 November]

Pendit, Putu Laxman. (2003). Penelitian IImu Perpustakaan dan Informasi. Jakarta: JIP-FSUI.

Punwono. (2010). Dokumentasi. Cetakan Pertama. Yogyakarta: Graha IImu

Rowlands, Ian and David Nicholas. 2005. Scholarly Communication in the digital environment : The 2005 Survey of Journal Author Behavior and Attitudes. Aslib Proceedings (2005) : hln. 481-497

Rubin, Richard E., (2004). Foundations of Library and Information Science, 2nd Edition. New York: NealSchuman Publisher.

Siswadi, Irman. (2009). "Perpustakaan Sebagai Mata Rantai Komunikasi IImiah (Scholarly Communication)" dalam Visi Pustaka: Majalah Perpustakaan 11 (1) April 2009: 1-9

Sulistyo-Basuki. (2009). "Pemahaman Singkat Mengenai Informatika" dalam Visi Pustaka: Majalah Perpustakaan 11 (1) April 2009: 30 $-33$

Sulistyo-Basuki. (1996). Dasar-Dasar Dokumentasi. Jakarta: Universitas Terbuka

Sulistyo-Basuki. Tanpa tahun. "Informasi, Komunikasi, dan IImu Perpustakaan \& Informasi" dalam Perpustakaan dan Informasi dalam Konteks 
Budaya. Jakarta: Departemen IImu Perpustakaan dan Informasi FIB UI.

Vickery, Brian, Alina Vickery. (1987). Information Science: in Theory and Practice. First published. London: Butterworths

Suwarno, Wiji. 2016. Library Life Style (Trend dan Ide Kepustakawanan). Yogyakarta: Lembaga Ladang Kata.

Yusup, Pawit M. (2009). IImu Informasi, Komunikasi, dan Kepustakaan. Cetakan Pertama. Jakarta: Bumi Aksara

Vickery, Brian, Alina Vickery. (1987). Information Science: in Theory and Practice. First published. London: Butterworths

Yuyuf, Pawit M. 2013. IImi Informasi, Komunikasi dan Kepustakaan. Jakarta : Bumi Aksara 